\title{
Fantasy in Literature: A Symbiotic Relation to the Real
}

\author{
Lekha Nath Dhakal, Ph.D. \\ Associate Professor, Nepal Commerce Campus, T.U.
}

\begin{abstract}
This article attempts to explore the use of fantasy in literature and how it has attained the position of a literary category in the twentieth century. This work also concerns howas the form literature, it functions between wonderful and imitative tocombine the elements of both. The article reveals that wonderful represents supernatural atmospheres and events. The story-telling is unrealistic which represents impossibility as it creates a wonderland. In the imitative or the realistic mode, the narrative imitates external reality. In it, the characters and situations are ordinary and real.Fantasy in literature does not escape the reality. It occurs in an interdependent relation to the real. In other words, the fantastic cannot exist independently of the real world that limits it. The use of fantastic mode in literature interrupts the conventional artistic representation and reproduction of perceivable reality. It embodies the reality and transgresses the standards of literary forming.It normally includes a variety of fictional works which use the supernatural and actually natural as well.The developers of fantasy fiction are fairy tales, science fiction about future wars and future world. A major instinct of fantastic fiction is the violence threatened by capitalist violation of personality that is spreading universally.
\end{abstract}

Keywords: fantasy, literature, supernatural, natural, fiction

According to Roger Fowler, "the combination of real and supernatural suggests a world of greater opportunity and fullness than one consisting of real elements alone" (88). He notes that it is the nature of fantastic text to confuse the reader about how to understand and react the events told. Some critics observe that the fantastic cannot occur without the belief of a clear dividing line between things possible according to the laws of nature and the things supernatural and impossible. Rosemary Jackson puts her opinion that "the fantastic is analyzed from a structuralist position looking at the narrative qualities of a mode and from a psychoanalytical perspective, considering these features as the narrative effects of basic psychic impulse" (7). Fantastic fiction is a creation if history. "Everybody ...agrees that it is not thinkable that overriding mythological or religious belief suffers an epochal political breakdown, as a consequence of which some of its aspects and elements become available for fictional manipulation" (Suvin, 214).

The confusion between the real and the supernatural usually centers on the storyteller's or the character's behavior. The main character separates himself from communication or conversation. Family, friends, career even everyday happenings become worthless and difficult to him. His lack of traditional values and need towards ideal perfection can take different forms. The effort to make life practicable becomes an attempt to transcend the human limits. The protagonist establishes an unconscious compensatory device and becomes more disordered and cannot think positively in a practical way. The effort to surpass one's limits calls in the reader a captivation which makes any blame unclear. 
Nowadays, criticism has focused on relations between fantastic text and the societies in which they appear. In industrial society, a person comes to see himself at the pity of forces which in fundamental ways escape his understanding. The fantastic tries to pay for a lack resulting from cultural boundaries. Fowler further says that "the fantastic gives indirect expression to doubts about itself which society refuses to entertain if they are directly stated; the protagonist's confusion arises from the urge to express aspects of himself which the society condemns and according for which no adequate language is available" (90). It defines that the real is physical and empirical and unreal is the metaphysical. Man can only represent reality through language and imagination. It is left open in infinite displacement. It is like retelling, redreaming, reinterpreting, re -memory and so on. It is the endless game of mirrors where meaning truly lies in the unconscious. One can understand meaning through language and imagination not through the perception. Brook-Rose observes: "Certainly what used to be called empirical reality, or the world, seems to have become more and more unreal, and what has long been regarded as unreal is more and more turned to or studied as the only true or another and equally valid reality" (5). The observed reality sometimes becomes unbearable and it is natural to turn to the fantastic as real. The real world and the world of fantasy are interconnected. Jack Zipes in his study of fairy tales shows how its tradition began in France in $18^{\text {th }}$ century. The tales' prime concerns were with giving counter to the ruling power and cruel oppression of that time by means of magic possibilities. He presents that magical and miraculous "represent metaphorically the conscious and unconscious desires of the lower classes to seize power" (7) to confirm a more just result at least for the protagonist.

Human being's need requires fantasy to execute significance on the self-doubt and glaring reality around him. Man finds himself decentralized in the modern times. The progress in modern science and technology questions the very possibility of an ordered and systematic world. Human beings feel insecure because of the idea of mortality, unknown fear, and change in life style. The idea of his own death makes him feel that his entire world of cognition is going to disappear which leaves him with endless anxiety. However, he manages to adjust himself with this by simply saying no to it through various fictions which in some way support his love in this mortal world to defeat the idea of death. Fantasy is the outcome of human desire which represents the undeniable fact. He senses that real has become unreal. Without any doubt, the present horizons require the painful rethinking of the situation of man. Therefore, in human desire for importance man looks for either moral meanings or mystical meanings.

Man suffers from a continuous fear of technological and scientific brutality. In the idea of Suvin, "...this rethinking does not mean an abandonment of ethical ideals and political imperatives, but it does mean a re-examination of all tools and mediations. ...but amid a deluge one has to use all means at hand, however, flimsy (215). Man is conscious that he cannot find these meanings in the real, visible world around him. Therefore, he searches for the moral and supernatural meanings of the real in fantasy. Fantasy does not only deny the real condition but also reflects them. The hostility that fantasy states is not nonconcrete. It is deep-rooted in the actual situation of nature and in existing social affairs. Fantasy is subversive, therefore, it advocates an alternative to these real conditions. It has a creative prospective and it leads to problemsolving activity.

Fantasy represents the imaginative desires of the people who wants a better future. it is always linked with desire. Tolkien knows that fantastic fictions "were plainly not primarily concerned with the possibility, but with desirability" (40). It is a form of writing having multiple meanings with its values and appeals. it makes use of allegory and symbolism. In fantasy, symbolism is closely connected to the elements of wonderful. The use of fantasy is to provide a wider frame of orientation which is representative of the genre. This quality, Jonathan Raban says, is important in the framework of fantastic narrative. According to him:

Symbolism may enable the writer to create a moral and intellectual frame work for the action of his novel. Symbolism may allow an author to link the limited world of his characters to one of the great systems of values, so that we are made to compare the happenings in the novel with their mythological or historical parallels. (100) 
Fantasy gives a newness of insight and enthusiasm in verbal wit which change the gravity of the message that the text pursues to convey. It is the need to communicate to the reader a vision of some kind of supreme reality. The primary world seems to have penetrating beauty of its own. This is frequently ignored within the restricted margins of modern life. But the beauties of the primary world differ according to the perception of different writers. The images of primary world are mostly drawn from the writer's unconsciousness. Such image appears in connection with the secondary world exists in the literary work. What has contributed to the desired effect in a fantastic fiction are the language, style and the words. Peter Schwenger detects that in the fantasy fictional genre, the readers will be affected by "what has been called syntactic imagery, where the shape and rhythm of sentences can express a nonverbal perception; so there is the sense of particular movement in space in relation to branches and oversized flowers" (68). One can take the example of Virginia Woolf's novel To the Light House (1968). Towards the conclusion of the first part of the novel there is a scene where husband and wife are alone in the sitting room and they reading. One can study the mind of Mrs. Ramsay through her book:

She opened the book and began reading here and there at random, and as she did so she felt that she was climbing backwards, upwards showing her way up under petals that curved over her, so that she only knew this white or this red. ... she read and the turned the page, swinging herself, zig-zagging this way and that, from one line to another as from one branch to another. (136)

one can easily understand that Mrs. Ramsay is in the exploration of something deeper though she does not know the actual meaning of the words. Even at the day end, she does not want to come up to the surface as she wants to escape the reality that she cannot face. Schwenger again puts forward that text is like a picture for the reader where one can see a scene and characters with one's inner eyes. He observes that "the purpose of these instructions is to produce vision and at the same time to restrain it from overflowing into promiscuously personal associations" (101).

It seems that the author while creating the literary text in the fantastic genre practices the means to limit the level of fantasy to project his own point of view. In the words of Schwenger: "For Jacques Derrida, the frame is 'the decisive structure of what is at stake' in fundamental questions of intrinsic and extrinsic, what is 'inside' and what is 'outside' the work of art" (100). The line between reality and unreality is unclear. The limitations are overlap. Therefore, it is very difficult for the readers to find out the distinctions between reality and passionately charged narrative. The fantastic stories engage the both: wonderful and imitative genre. Eric Rabkin in a most famous book The Fantastic in Literature, expresses his opinion that "the fantastic confusion of the external and internal worlds is the most common device of art and is found even more frequently in the more highly fantastic art" (221).

The fantastic form in literary works makes use of certain conventions of representative fiction to declare that whatever it tells is real and then continues to subvert reality by presenting what is clearly dreamlike or wonderful. Fantasy as a literary work has certain tradition. Readers, sometimes, hesitate between the two possibilities and sometimes the characters have to face the same problem. They are totally confused to identify the dividing line between the marvelous and the mimetic. The famous author Todorov notes that "recent French definition of fantastic, if they are not identical with ours, do not on the other hand contradict it... The fantastic is always a break in the acknowledged order, an eruption of the inadmissible within the changeless everyday legality" (25). For Rosemary Jackson, "fantasy does not invent supernatural regions, but present a natural world inverted into something strange, something other. It becomes domesticated, humanized, turning from transcendental explorations to transcriptions of a human condition" (17). It connects to Suvin's concept that fantasy presents a different perception of history. In "Considering the Sense of Fantasy or Fantastic Fiction," Suvin further presents that human activities are frequently reduced to "personal power relationships around or among the principal narrative agents: it is only within such relationships that interest in abrogating our empirical physical laws" (221).

Toni Morrison's novels analyses that the mode of fantasy in literature operating within fiction does not escape the reality. Through imagination, it generates a world very similar to the real world. Morrison 
is more concerned with the social and personal lives of her people specially the African-American people. She is eager to know their internal lives, history and the way they live. She presents the reality by using the elements of fantasy in her fiction. She writes the stories that have historical reality, gives them to vivid imagination and tempers them with fantasy in order to change them into fictional reality that voice her genuine concerns. In her novel Sula Morrison defines Sula's death and very calmly remarks that "she noticed that she was not breathing, that her heart had stopped completely" (15o).

Here, the half sentence 'she noticed that' records Sula's mystical experience into human language. Sula only notices, but does not say anything. The story-telling tricks the readers into trusting to be real whatever they read about, while they know that the dead is not able to speak and think. The use of fantasy here defamiliarizes the familiar and real. Here the readers are taken away from the seemingly real world where death is an inactive state, into a wonderful world where the death can actively think and feel. Readers are confused whether the truth is really true or not. Sula observes her mother burn to death. She has no emotion and feelings of that. She is completely detached from it. Her feeling of aesthetic pleasure as she looks at her mother being eaten by fire is really odd. The stories in fantastic mode of literature is made up of contraries.

When writing on the structural contradictions of fantastic fiction, Joanna Russ observes the fantastic with its breaking of reality: "Fantasy embodies a negative subjunctivity - that is, fantasy is fantasy because it contravenes the real and violets it. The actual world is constantly present in fantasy by negation ... and insists on the denial throughout" (52). Location, settings, characters and situations in Morrison's narrative opposes reality and violets it. In Sula, Eva's love for her son Plum confuses the readers. She kills Plum to protect him from self - destruction. It denies any assumption of love. Her negative desire "expresses itself as a violent transgression of all human limitation and social taboos prohibiting the realization of that desire" (Jackson 56). In Beloved (1987), slave mothers kill their children to protect them from dehumanizing act of slavery. Cholly rapes his own daughter to express the tenderness and affection towards her in The Bluest Eye (1970). This is a direct breaking of reality. Pilate's character without a navel in Song of Solomon (1977) is a violation of reality, an impossibility, it collects a certain amount of reliability in story-telling. But it is insisted upon as the truth till the very end in the novel.

Thus, fantasy in literary works generates a world where people warmly respond with a spacetime that rejects history as being socially and economically legal. The fantastic mode which displays the concerns about the steady finding of wicked and superior forces that lie below the realistic surfaces of being. It is not the type of fantasy and fear predicted in horror stories or in science fiction. It is different from the purely amazing stories cast in an unusual world of unreality beyond space and time. Fantastic literature is also connected with some kind of existential worry. It is not merely a thematic feature but is combined into the construction of effort to become its crucial component. Anxiety in story is stimulated by the powerlessness of the character or the community either to come to terms with or sack totally the seemingly unreal happenings told.

\section{Works Cited}

Brooke-Rose, Christine. A Rhetoric of the Unreal: Studies in Narrative and Structure, Especially of the Fantastic. Cambridge University Press, 1981.

Fowler, Roger. A Dictionary of Modern Critical Terms. Routledge and Kegan Paul, !993.

Jackson, Rosemary. Fantasy: The Literature of Subversion. Methuen, 1981.

Lacan, Jacques. Four Fundamental Concept of Psychoanalysis. Trans. Alan Sheridan. Penguin,1979.

Morrison, Toni. Song of Solomon.Signet, 1977.

--- . Sula. Plume, 1973.

--- . The Bluest Eye. Chatto and Windus, 1981.

Raban, Jonathan. The Technique of Modern fiction. University of Notre Dame Press, 1969.

Rabkin, Eric S. The Fantastic in Literature. Princeton University Press, 1976. 
Russ, Jonna. "The Subjunctivity of Science Fiction.” Extrapolation 15.1(2000): 51- 58.

Schwenger, Peter. Fantasm and Fiction: On Textual Envisioning. Stanford University Press, 1999.

Suvin, Darko. "Considering the Sense of Fantasy or Fantastic Fiction: An Effusion." Extrapolation 41.3(2000): $209-247$.

Todorov, Tzvetan. The Fantastic: A Structural Approach to a Literary Genre. Cornwell University Press, 1975.

Tolkein, J.R.R. “On Fairy - Stories.” The Tolkein Reader. Ballantine, 1973.

Woolf, Virginia. To the Light House. Penguin, 1968.

Zipes, Jack. Fairy Tales and Art of Subversion. Wildman, 1983. 
Issue 1 May/June 2020 - 